UDC 330.4

\title{
Statistical and Econometrical Assessment of the Labor Market Impact on Other Economic Indicators by Economic Regions
}

\author{
Rustamov Elnur \\ Azerbaijan State University of Economics (UNEC), Baku, Istiqlaliyyat str.6, AZ1001 \\ Azerbaijan, e-mail: elnur706@gmail.com
}

Suleymanov Arzu

Head of The Chair of Economics and Statistics, Azerbaijan Technical University, Baku, Hasan bay Zardabi str. 88, AZ 1011 Azerbaijan, e-mail: suleymanov.arzu@gmail.com

\begin{abstract}
The balanced socio-economic development of the country's regions arises from the balanced development of several economic systems. For this, the most important factor is to determine areas that stimulate development at an early stage. Thus, the growth of all economic sectors at the same rate does not mean the formation of a generally balanced development. For this, the composition of the economic process and the role of the labor market in the motivating factors must always be measured. A question arises, what is the importance of the division of the role of the labor market in these areas? Firstly, the main goal should be to achieve economic development and prosperity. Economic development itself will regularly play the role of impetus in the development of the social sphere. In general, the end result of all economic processes is to further improve the social welfare of the population. Taking into account the above mentioned, the impact of labor market indicators on other economic indicators for the regions of the country was assessed and analyzed in accordance with international methodology. For this, the economic indicators of the last 20 years were taken and the research work was conducted. The research identified main shortcomings and their solutions were shown in accordance with international methodologies. To this end, research is needed to be conducted to identify shortcomings that are always lacking in order to achieve full results in economic policies in future.
\end{abstract}

Keywords: labor market, economic growth, economic region, correlation-regression, statistical analysis.

\section{Статистическая и эконометрическая оценка влияния рынка труда на Аругие экономические показатели по экономическим регионам}

Рустамов Эльнур

Азербайджанский Государственный Экономический Университет (UNEC), Баку, ул. Истиглалият 6, AZ1001 Азербайджан, e-mail: elnur706@gmail.com

Сулейманов Арзу

Заведующий кафедрой экономики и статистики, Азербайджанский Технический Университет, Баку, ул. Гасанбека Зардаби 88, AZ 1011 Азербайджан,

$(\infty))_{B Y}$

e-mail: suleymanov.arzu@gmail.com 
Аннотация. Сбалансированное социально-экономическое развитие регионов страны является результатом сбалансированного развития нескольких экономических систем. Для этого наиболее важным фактором является определение направлений, стимулирующих развитие на ранней стадии. Таким образом, рост всех секторов экономики одинаковыми темпами не означает формирования в целом сбалансированного развития. Для этого всегда необходимо измерять состав экономического процесса и роль рынка труда в побуждающих факторах. Возникает вопрос, в чем важность разделения роли рынка труда в этих сферах? Во-первых, главной целью должно быть достижение экономического развития и процветания. Само экономическое развитие будет регулярно играть роль толчка в развитии социальной сферы. В целом, конечным результатом всех экономических процессов является дальнейшее улучшение социального благосостояния населения. Принимая во внимание вышеизложенное, влияние показателей рынка труда на другие экономические показатели регионов страны было оценено и проанализировано в соответствии с международной методологией. Для этого были взяты экономические показатели за последние 20 лет и проведены исследовательские работы. В ходе исследования были выявлены основные недостатки и показаны способы их устранения в соответствии с международными методологиями. С этой целью необходимо провести исследование для выявления недостатков, которых всегда не хватает для достижения полных результатов экономической политики в будущем.

Ключевые слова: рынок труда, экономический рост, экономический регион, корреляционно-регрессионный анализ, статистический анализ.

DOI: $10.31432 / 1994-2443-2021-16-2-51-58$

Цитирование публикации: Рустамов Э., Сулейманов А. Статистическая и эконометрическая оценка влияния рынка труда на другие экономические показатели по экономическим регионам // Информация и инновации. 2021, Т. 16, № 2. с. 51-58. DOI: 10.31432/1994-2443-2021-16-2-51-58

Citation: Rustamov E., Suleymanov A. Statistical and Econometrical Assessment of the Labor Market Impact on Other Economic Indicators by Economic Regions // Information and Innovations 2021, T. 16, № 2. p. 51-58. DOI: 10.31432/1994-2443-2021-16-2-51-58

\section{Introduction}

The balanced socio-economic development of the country's regions is the result of the balanced development of several economic systems. Hence, the initial stage of development, the most important factor in determining which bodes areas. Thus, the formation of balanced growth of all economic sectors is not the same as the increase in power. For this, the factors contributing to the economic process, the composition and role of the labor market will always be measured. Overall, the labor market, along with other indicators, this analysis should be performed on all types of economic activity. This begs the question, what is the significance of the division of the role of the labor market in these areas? For an explanation of the importance of several factors play a major role. The first economic development and 
well-being should be the main target of achieving. For this reason, it is expedient to study the components of economic activities that will be important to us in the process of economic development at the initial stage.
Economic growth in itself will act as a boost to the development of the social sphere on a regular basis. In general, the end result of all economic processes is to further improve the social welfare of the population (Table 1).

\section{Real situation in Azerbaijan}

Table 1.

\section{Gross output in the regions of the country, as a percentage of the total}

\begin{tabular}{|l|l|l|l|l|l|l|}
\hline & $\mathbf{2 0 1 0}$ & $\mathbf{2 0 1 5}$ & $\mathbf{2 0 1 6}$ & $\mathbf{2 0 1 7}$ & $\mathbf{2 0 1 8}$ & $\mathbf{2 0 1 9}$ \\
\hline Country & 100 & 100 & 100 & 100 & 100 & 100 \\
\hline Baku city & 77.3 & 70.3 & 71.7 & 71.3 & 72.3 & 68.2 \\
\hline Absheron economic region & 1.5 & 2.7 & 2.9 & 2.9 & 3.5 & 6.0 \\
\hline Ganja-Gazakh economic region & 4.0 & 4.8 & 4.5 & 4.7 & 4.3 & 4.7 \\
\hline Shaki-Zagatala economic region & 1.7 & 2.0 & 1.9 & 2.0 & 1.9 & 2.1 \\
\hline Lankaran economic region & 1.8 & 2.5 & 2.5 & 2.4 & 2.2 & 2.0 \\
\hline Guba-Khachmaz economic region & 2.4 & 2.1 & 2.0 & 2.1 & 2.0 & 2.4 \\
\hline Aran economic region & 6.5 & 8.5 & 7.7 & 8.3 & 8.0 & 8.5 \\
\hline Yukharı Garabagh economic region & 0.6 & 0.7 & 0.7 & 0.8 & 0.6 & 0.7 \\
\hline Kalbajar-Lachın economic region & 0.1 & 0.1 & 0.1 & 0.1 & 0.1 & 0.1 \\
\hline Daghlig Shirvan economic region & 0.9 & 1.0 & 1.0 & 1.0 & 1.0 & 1.2 \\
\hline Naxchıvan Autonomos Republic & 3.2 & 5.3 & 5.0 & 4.4 & 4.1 & 4.1 \\
\hline
\end{tabular}

Source: [1.www.stat.gov.az/source/system_nat_accounts/az/034.xls]

The division of the country, such as product launches was seen from the table. According to this division, the main output falls on the city of Baku. There is a discrepancy in the distribution of products between the regions. According to the division, the next places are occupied by Aran, Absheron and Ganja-Gazakh economic regions. Other economic regions have a very small share in the distribution of shares[13. http://static.president.az/pdf/38542.pdf ] (Table 2).

If we look again at the distribution of the employed population by economic regions over the years, it is clear that Baku, Aran, Absheron, and Ganja - Gazakh economic regions have the main share in the distribution 


\section{The number of employed people by economic regions, as a percentage of the total}

\begin{tabular}{|l|l|l|l|l|l|l|}
\hline & $\mathbf{2 0 1 0}$ & $\mathbf{2 0 1 5}$ & $\mathbf{2 0 1 6}$ & $\mathbf{2 0 1 7}$ & $\mathbf{2 0 1 8}$ & $\mathbf{2 0 1 9}$ \\
\hline Country & 100 & 100 & 100 & 100 & 100 & 100 \\
\hline Baku city & 24.4 & 23.9 & 24.0 & 23.9 & 24.0 & 24.1 \\
\hline Absheron economic region & 5.9 & 5.8 & 5.8 & 5.8 & 5.8 & 5.7 \\
\hline Ganja-Gazakh economic region & 13.3 & 13.3 & 13.3 & 13.4 & 13.3 & 13.3 \\
\hline Shaki-Zagatala economic region & 6.4 & 6.4 & 6.4 & 6.4 & 6.4 & 6.4 \\
\hline Lankaran economic region & 8.8 & 8.9 & 8.9 & 8.9 & 8.9 & 8.9 \\
\hline Guba-Khachmaz economic region & 5.3 & 5.3 & 5.3 & 5.3 & 5.3 & 5.3 \\
\hline Aran economic region & 19.6 & 19.7 & 19.7 & 19.7 & 19.7 & 19.6 \\
\hline Yukharı Garabagh economic region & 6.0 & 6.1 & 6.1 & 6.1 & 6.0 & 6.0 \\
\hline Kalbajar-Lachın economic region & 2.5 & 2.5 & 2.5 & 2.5 & 2.5 & 2.5 \\
\hline Daghlıg Shirvan economic region & 3.0 & 3.1 & 3.1 & 3.1 & 3.1 & 3.1 \\
\hline Naxchıvan Autonomos Republic & 4.9 & 4.9 & 4.9 & 4.9 & 4.9 & 5.0 \\
\hline
\end{tabular}

Source: [2.https://www.stat.gov.az/source/labour/az/001_1.x/s]

by economic regions [10. https://www.eviews. com/home.html]. However, the weakness lies in the fact that a certain part of the working population is concentrated in this economic region. Based on this fact, along with the problem of demographic density in urban centers has led to the accumulation. Overcome this problem by itself will prevent the flow of people in the central cities. The existence of problems in providing the population with jobs in order to obtain their wages more in big cities has led to the migration. Another factor here is the concentration of large businesses in the capital and surrounding economic regions. Here are a few factors that play a key role. In particular, there is a skilled workforce in the human resources of the newly created entity can be held comfortably. Another factor will be the ease of supply of raw materials to the enterprise and the delivery of finished products to consumers. The main factor here is the extent to which the company is close to a transport hub [3. https://www.economy.gov. az/article/state-programs/21429].

In addition, in recent years, the development of the non - oil sector, which is one of the most important parts of economic policy, has become almost an important element. Thus, the impact of pandemic processes on energy prices in the world economy has sharply reduced the prices of these products. Given the above in their economic policy, the countries 
have given priority to the development of nonoil sectors. Based on the development of this area distributed by regions of the country will create the basis for the full implementation of economic policy [4. http://edf.gov.az/uploads/ Teqdimat/Hesabat\%20Vebsayt\%20Final. pdf].

\section{Statistic evaluation of the factors that have an impact on non-oil export in the Republic of Azerbaijan}

In our study, we tried to assess the impact of the number of employed people on non-oil exports in the country. The database is based on the annual indicators of the State Statistics Committee of the Republic of Azerbaijan for 1995 - 2018. Indicators of thousand people employed in non-oil exports to the Central Bank for years, the average annual exchange rates of the US dollar compared to manat was calculated million manat.

Evaluation of econometric regression equation was chosen as the methodological approach. The model was empirically implemented in the EViews 9 statistical software package.
Table 3.

\section{Correlation coefficient}

$\begin{array}{lll} & \text { Non-oil export } & \text { Employment } \\ \text { Non-oil export } & 1.00 & 0.84 \\ \text { Employment } & 0.84 & 1.00\end{array}$

The results show that there is a strong linear relationship between employment and non-oil exports (0.84). This gives us a basis for constructing the regression equation in a linear form (Table 4).

The deviations of 2004-2005 were eliminated by adding a false variable. The coefficients of determination (R-squared $=0.951$ ) and the Durbin Watson coefficients (1.51) suggest that the model is adequate. Thus,

\section{Non-oil export $=$ $-5908.18+1.53 *$ Employment}

The results show that a 1-unit increase in employment will increase non-oil exports by 1.73 units.

Graphic representations of balances were as follows:

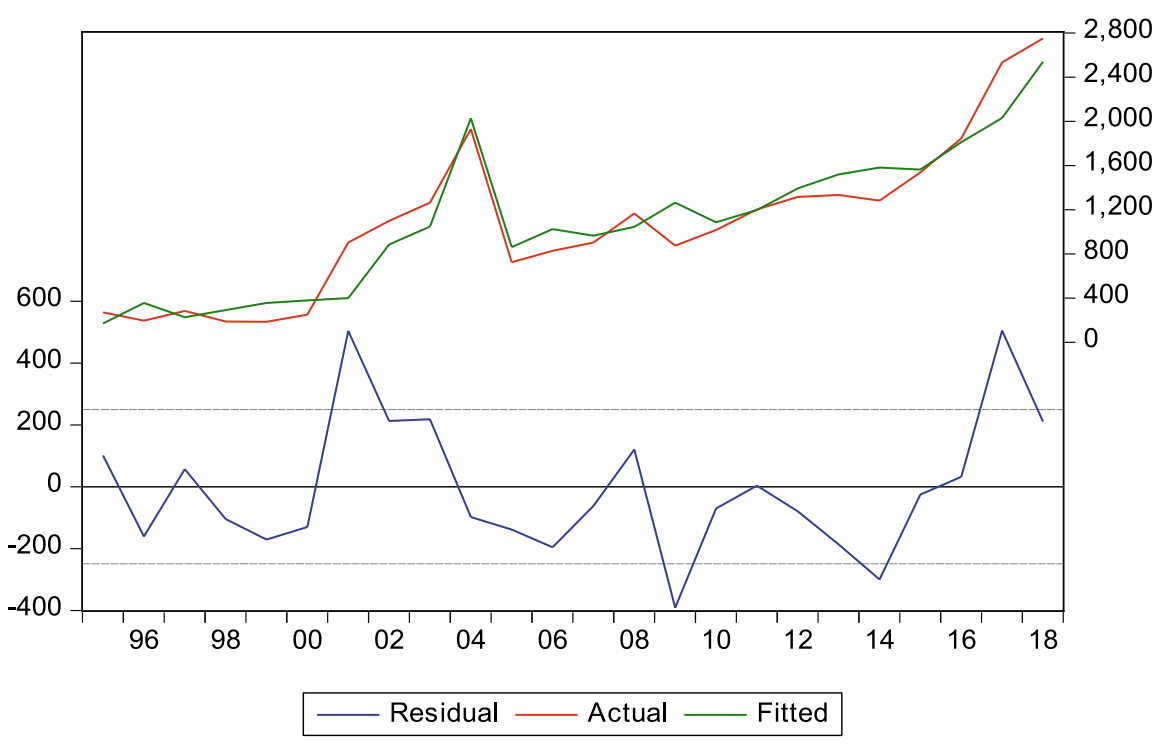

Figure 1: Graphical description of the remains of the model 


\section{Evaluation impacts of employment on non-oil exports}

Dependent Variable: NONOIL_EXPORT

Method: ARMA Maximum Likelihood (OPG - BHHH)

Date: 23/05/21 Time: 15:48

Sample: 19962018

Included observations: 24

Convergence achieved after 15 iterations

Coefficient covariance computed using outer product of gradients

\begin{tabular}{|c|c|c|c|c|}
\hline Variable & Coefficient & Std. Error & t-Statistic & Prob. \\
\hline EMPLOYMENT & 1.526293 & 0.332003 & 5.199631 & 0.0001 \\
\hline C & -5908.179 & 1450.795 & -4.210643 & 0.0005 \\
\hline$T=2004$ & 836.7953 & 393.0252 & 2.129113 & 0.0473 \\
\hline$T=2005$ & -230.7168 & 279.2772 & -0.826121 & 0.4196 \\
\hline $\operatorname{AR}(1)$ & 0.707240 & 0.205727 & 3.437767 & 0.0029 \\
\hline SIGMASQ & 46527.50 & 15441.59 & 3.013129 & 0.0075 \\
\hline R-squared & 0.951109 & \multicolumn{2}{|c|}{ Mean dependent var } & 1078.081 \\
\hline $\begin{array}{l}\text { Adjusted } \\
\text { R-squared }\end{array}$ & 0.873639 & \multicolumn{2}{|c|}{ S.D. dependent var } & 700.6781 \\
\hline S.E. of regression & 249.0716 & \multicolumn{2}{|c|}{ Akaike info criterion } & 14.11457 \\
\hline $\begin{array}{l}\text { Sum squared } \\
\text { resid }\end{array}$ & 1116660. & \multicolumn{2}{|c|}{ Schwarz criterion } & 14.40909 \\
\hline Log likelihood & -163.3749 & \multicolumn{2}{|c|}{ Hannan-Quinn criter. } & 14.19271 \\
\hline F-statistic & 32.80378 & \multicolumn{2}{|c|}{ Durbin-Watson stat } & 1.513119 \\
\hline Prob(F-statistic) & 0.000000 & & & \\
\hline Inverted AR Roots & 0.71 & & & \\
\hline
\end{tabular}

When assessing the impact of employment on non-oil exports, it is clear that the coefficients of the equations are highly valued as a positive result of the measures taken. Using the results of the study will be made in the projections can be used in future.
It is also clear from the established econometric model that the country's employment sector is directly related to non-oil exports [8. http://xaricdetehsil.edu.gov.az/]. For this reason, after implementing a non-oil strategy at the regional level, it is possible to strengthen 
the country's economy through its exports, which in turn will help solve the economic problems of the regions. Implementation of foreign exchange inflows into the country will not only increase the volatility of the manat, but also allow it to control its stable exchange rate. All these processes must be implemented using international methodologies. In that sense, if the quality of goods and services produced in the country will be up to the standards that prune to improve the future of our country as a country to join the World Trade Organization will contribute to a full-fledged [9. www.cbar.az/page-43/external-sector-statistics]. Taking into account all the above, it should be noted that economic development, both at the national and regional levels, will not be possible without labor market factors. In all three, the development of this area should always be in the center of attention. For the development of this field, the constant training of professionals is a priority. One of the main parts of the youth policy implemented in the country for more than 10 years is the return of young people to their homeland by studying abroad at public expense and the state's support for these young people on the way to the highest level of education. It should be noted that labor market participants must constantly increase their competitiveness in the production of goods and services. That is, both employees and employers should be interested in improving the knowledge and skills of the workforce. On the basis of the "State Program on Education of Azerbaijani Youth Abroad for 2007 - 2015" approved by the Order of the President of the Republic of Azerbaijan and the relevant legal acts adopted annually as a continuation of that program, many Azerbaijani youth study bachelor's, master's and doctoral degrees and continue to make a significant contribution to the development of relevant sectors of the country's economy with their knowledge and skills by returning to our country. One of the main goals is to achieve further development of the country's economy in the future by taking advantage of the knowledge and skills of such young people. In addition, it should be noted that the country's universities are undergoing serious reforms to bring the level of education to the level of higher-ranking universities, which in turn will ensure the training of highly qualified personnel in the future and their more productive work [7.azstat.org/ onlinedoc/d03102410.rar]. At the same time, during the period of employment, employees must be constantly retrained, retrained and constantly improve their work skills. As a result of this implementation, the World Economic Forum's annual ranking of the world's countries implemented the country's Human Development Capital is ranked each year on the front steps[6. http://iqtisadiislahat. org], [11. http://www3.weforum.org/docs/ WEF_Human_Capital_Report_2018.pdf]. It is necessary to note that, in different phases of economic development impact on the labor market can reach the established goals. Increasing the overall economic development of Azerbaijan and achieving the set goals is one of the main priorities. To this end, the country's export - oriented economic model based on the transformation of high value added export - oriented economy has been identified as the main priority, which is the main driving force of the economy through the development of non-oil sector is targeted to expand export opportunities. The "Strategic Roadmaps for the National Economy and Key Sectors of the Economy" approved by the Decree of the President of the Republic of Azerbaijan dated December 06, 2016, repeatedly emphasizes the increase in both the country's GDP and non - oil exports[5. https://azexport.az/]. The establishment of the "Made in Azerbaijan" brand and the "One Window" Export Support Center should be considered as 
one of the successful steps taken to expand export opportunities. The modern phase of development of the knowledge-intensive areas of the labor market more focused on the future development of these areas to develop istirakcıalrının pave the way [12. https://president.az/articles/17535].

\section{Conclusion}

The article notes that in order to achieve socio-economic development at the regional level, there is a constant need to improve economic policy. It is emphasized that there is a need to study this area due to the fact that the labor market is at the center of all economic processes. The article analyzes the current situation using the indicators of employed population and output by economic regions in 2010-2019. In addition, the impact of the employed population on the non-oil sector was studied using the indicators of 1996-2018. For the continuous development of all economic processes in the future, the components of the labor market should be studied by regions of the country, and the deficient parts should always be directed to development, so that economic decisions create the basis for balanced development of the country's regions. International methodologies were used in conducting this analysis.

\section{REFERENCES}

1. URL: https://www.stat.gov.az/source/ system_nat_accounts/az/034.xls

2. URL: https://www.stat.gov.az/source/ labour/az/001_1.xls

3. URL: https://www.economy.gov.az/article/state-programs/21429

4. URL: http://edf.gov.az/uploads/Teqdimat/Hesabat\%20Vebsayt\%20Final.pdf

5. URL: https://azexport.az/

6. URL: http://iqtisadiislahat.org/store// media/documents/diger/Rayonlarin_Investisiya_Reytinqi_.pdf

7. URL: www.azstat.org/onlinedoc/ d03102410.rar

8. URL: http://xaricdetehsil.edu.gov.az/

9. URL: www.cbar.az/page-43/external-sector-statistics

10. URL: https://www.eviews.com/home. html

11. URL: http://www3.weforum.org/ docs/WEF_Human_Capital_Report_2018.pdf

12. URL: https://president.az/articles/17535

13. URL: http://static.president.az/ pdf/38542.pdf 